\title{
Relationship between Perceived Father Involvement and Early Adolescent's Subjective Well-Being
}

\author{
Hilmia $^{1}$, Eko Handayani ${ }^{2 *}$ \\ 1,2. Faculty of Psychology, Universitas Indonesia, Depok, Indonesia \\ *E-mail: handayanieko2@gmail.com
}

\begin{abstract}
;
The aim of this research is to investigate the relationship between perceived father involvement and early adolescent's subjective well-being. Participant in this research were 162 early adolescents 12-15 years old. Nurturant fathering Scale (NFS) dan Father Involvement ScaleReported (FIS-R) by Finley and Schwartz (2004) is used to measure father involvement. For measuring subjective well-being, we used Satisfaction With Life Scale (SWLS) from Diener (1985) and Positive and Negative Affect Schedule (PANAS) by Watson, Clark, and Tellegan (1988). We used the Pearson correlation to measure correlation between variables. The result indicated that domain father nurturance and domain reported father involvement is positively significant related to positive affect, and also found that domain father nurturance is negatively significant related with negative affect.
\end{abstract}

Keywords: early adolescent; perceived father involvement; subjective well-being

\section{Introduction}

Early adolescence is a critical period in life (Cripps \& Zyromski, 2009). Adolescent will face the transition from children to adult in this phase (Papalia \& Martorell, 2014). Monks, Knoers and de Vegt (2002) classified early adolescent to be in the age range 12 to 15 years. In early adolescence, they will experience significant changes in physical, cognitive and psychological aspects (Papalia \& Martorell, 2014). Adolescent will experience significant hormonal and physical changes as a sign of puberty, such as the first menstruation for girls and the first ejaculation for boy. Adolescent also will face significant changes in the social environment, such as the greater influence of peers and the wider social environment (Papalia \& Martorell, 20XX; Ellison, 1990). As early adolescent experience these changes, they often find problems in their lives (Mombelli, Costa, Marcon, \& Moura, 2011; Kristensen et al., 2004 in Nastasi \& Borja, 2016). Such problems include lack of parental support, complicated education systems, poor quality of life, adaptation issues to friendships and social environment, and quarrel with peers or siblings. These problems can be found in real life. There was recent news in January 2017 on some local news about 13-year-old boy who founded in the flow of Taman Sunter, Tanjung Priok (Ramadhan, 2017). The child who felt stress and decided to end his life by plunging into the river. Another teenager is Ghaessani (2011) who writes on his blog that he feels stress and depression due to the hectic and repetitive schedule routine. Ghaessani (2011) often feels sad and angry all of a sudden. Ghaessani feels that because of the problem it makes her have an idea to commit suicide. Unlike Ghaessani, Rizqi (2011) also wrote on his blog that he felt depressed because of his bad social friendship with his friends. Rizqi often feels alone and feel lonely in dealing with life problems. Rizqi (2011) also wrote that inharmony family and father's ignorance were sources of the stress.

The problems experienced by teenagers can make them become stress and lead to depression (Papalia \& Martorell, 2014). Therefore that subjective well-being in early adolescence is very important because it relates to how they will see themselves face problems in his life (Diener \& and Scollon, 2003). When adolescents have high subjective well-being, they will see their lives become more positive and tend to deal with problems in their life (Özdemir, 2012). Subjective well-being (SWB) was often associated with happiness, peace, and life satisfaction (Diener, Oishi, \& Lucas, 2003). According to Diener, 
Oishi, and Lucas (2003) SWB related to how people evaluate their lives in the present and for longer periods, such as evaluating life over the past year. These evaluations include emotional reactions to events, their moods, and their evaluation of the fulfillment and satisfaction of their lives. According to Diener (1984, in Özdemir 2012), SWB is a multidimensional construct consisting of two dimensions, the cognitive dimension, and affective dimension. The cognitive dimension is manifested by life satisfaction, and the affective dimension is manifested by positive and negative affection.

A study from Eryilmaz (2011) proves that SWB in adolescent can improve the ability to determine life goals and improve adaptation skills. Also, adolescents with high SWB may also work better in their social environment (Diener \& Diener, 1995; Özdemir, 2012). Adolescent who has low SWB tend to have the low level of happiness, low life satisfaction, and low self-evaluation as well and this condition can lead to high level of distress (Amato, as cited in Cripps \& Zyromski, 2009) and depression (Flouri \& Buchanan, 2003).

SWB is influenced by individual factor and social factor (Nastasi \& Borja, 2016). Individual factors are inherent and inborn factors, while social factors are factors outside of the self (Nastasi \& Borja, 2016). Individual factors affecting SWB are biological, physical, psychological conditions (Özdemir, 2012). Hewitt, Suldo \& Shaffer as cited in Özdemir, 2012) and Nastasi and Borja (2016) mentioned that coping stress, ability to relate to others, self-esteem problem-solving skills, and self-efficacy is also including the individual factor. Social factors are factors outside the selfadolescent, such as family relationships, family history, adult and adolescent relationships, parenting or family conflicts (Özdemir, 2012; Nastasi \& Borja, 2016). Social factors can be encouraged by parents, teachers and the environment around adolescents to increase SWB. Therefore the environment and interaction between people in the environment have an important role in SWB (Nastasi and Borja, 2016). Parenting still the main issue in adolescent (Papalia \& Martorell, 2014). Maternal care mostly seems through parenting activities such as preparing food, clothes and another nurturing activities. While father involvement is more about joining play activities, learning or activities related to cognitive abilities (Lamb, 1986).
Paternal involvement tends to increase in leisure activities with adolescents compared to mothers (Hosley \& Montemayor in Phares, Fields, \& Komboukos, 2009). This is because the mother's nurturing more decrease and gives more opportunities for the father to be involved (Lamb, 1986). Father is also more comfortable and competent and looks more interested in activities to spend spare time with older children. The existence of the father in adolescent life has also been investigated by Amato (as cited in Flouri \& Buchanan, 2003) which showed consistent results that the involvement of the father who lives with the child shows more beneficial to the child than the involvement of a non-resident father. Therefore, father involvement in parenting becomes a very important thing for adolescent development.

Related to the relationship of father involvement with SWB, a study of parent control relationship and parental warmth with SWB has been investigated by Özdemir (2012). The results of Ozdemir's study (2012) showed that the warmth of the father has a significant positive relationship with life satisfaction and positive affection and negatively related with adolescent negative affection. Warmth in nurturing is a small part of father's involvement. This is explained by Hofferth and Carlson (as cited in Lamb, 2010) about qualitative father involvement which includes father's control and father's warmth to children. In the operational explanation of "spending time" in dad's involvement, research finds that when spending time with children, fathers have an opportunity to show their child's warmth, monitoring, support and control such as disciplining children or appropriate rules for children (Hofferth \& Carlson, 2003 in Lamb, 2010).

Therefore, we are interested in investigating the relationship of warmth and parental control, especially in father involvement. The purpose of this study is to determine whether there is a relationship between perceive father involvement and early adolescents' subjective well-being. The hypothesis of this study is there is a relationship between perceived father involvement and early adolescent's subjective well-being. 


\section{Methods}

Sample. Participants were 162 adolescents 12-15 years old who had whole family structure (have father and mother, married status and living together). The sampling technique used in this research is accidental sampling.

Research Design. This study was a nonexperimental-correlational study with one shot study. This study was retrospective.

Instrument and Measurement. There are two measuring instruments used to measure SWB, which is Diener's Satisfaction With Life Scale (SWLS) to measure the cognitive dimensions of SWB and Positive and Negative Affect Schedule (PANAS) by Watson, Clark \& Tellegan (1988). SWLS consists of 5 items that measure life satisfaction with 7 scales from 1 "Strongly disagree" scale to 7 "Strongly agree" scale. The score obtained from the total score of the five items and the score range is from 7 to 35 . SWLS which has been adapted into Indonesian by Ghibran (2010) with reliability of 0.768. Diener, Emmons, Larsen \& Griffin (1985) has made the SWLS score category, ranging from very dissatisfied with the range of 5-9 scores to the category very satisfied with the score range 31-35. PANAS contains 20 lists of emotions, each of 10 positive emotions and negative emotions. PANAS consists 5 scales from 1 "very slightly or not at all" scale to 5 "extremely" scale. PANAS also has been adapted for early adolescent by Oriza (2016) with reliability coefficient of PA 0.81 and 0.85 for NA.

The measurement of father involvement in this study are Father Involvement Scale and Nurturant Fathering Scales: Retrospective Measures for Adolescent and Adult Children, a measure of father involvement developed by Finley and Schwartz (2004). Finley and Schwartz (2004) measuring instruments are divided into two measuring instruments, namely Nurturant Fathering Scale and Father Involvement Scale. The Nurturant Fathering Scale (NFS) measurements contain questions related to the quality of affection between father and child. NFS consists of 9 items and uses 5 points of scale that participants use to describe their relationship with the father. The second measurement is Father Involvement Scale-Reported (FIS-R). FIS contain question-related to father involvement in 20 child life domains, for example, the aspects of intellectual development, career development, and physical development. In each domain, participants are required to complete ranging from 1 "never involved" to 5 "always involved." FIS-R has three subscales that are instrumental involvement, expressive, monitoring involvement. We used are NFS and FIS-R that have been adapted into Indonesian and have been tested to early adolescents by Nugrahani (2014) with a reliability coefficient of NFS of 0.75 and FIS-R reliability of 0.88 .

These studies use descriptive analysis techniques, Pearson Correlation, Independent Sample T-Test and One-way Analysis of Variance (ANOVA) to process and analyze data about relationship between receiving father involvement and subjective well-being.

\section{Results}

The data from participants showed that most $(56 \%)$ of the participants were female and dominated by the age of 14 years with a percentage of $49 \%$. The data showed that $67.3 \%$ father's age is in the middle adult with the age range about 41-60 years old and 55.6 \% father's recent education is high school graduates.

Table 1.

Descriptive Result

\begin{tabular}{llll}
\hline Variable & Range & Mean & SD \\
\hline SWB & & & \\
Life Satisfaction & $7-34$ & 23.4 & 5.53 \\
Positive Affect & $21-60$ & 45.5 & 7.96 \\
Negative Affect & $11-52$ & 27.8 & 8.44 \\
\hline \multicolumn{2}{l}{ Father Involvement } & & \\
NFS & $1.9-4.8$ & 3.6 & 0.67 \\
FIS-R & $1.7-5.0$ & 3.4 & 0.63 \\
\hline
\end{tabular}

According to table 1, The result showed that the average life expectancy score of participants as measured by SWLS is 23.4 and the standard deviation is 5.53 . The average positive affection score was 45.5 higher than the average negative affective score of 27.8. In the measurement of father involvement, Mean score of NFS was higher than FIS-R.

In Table 2 we saw that most of the participants $(32.7 \%)$ are in the satisfied lifespan with the score of 26-30. Most (56\%) of participants also had father involvement in high NFS scores. 
Table 2.

Classification of SWB Score Results

\begin{tabular}{llcc}
\hline Range score & Categorize & Frequency & Percent \\
\hline \multicolumn{2}{c}{ Life Satisfaction (Satisfaction } & With Life & Scale) \\
$10-14$ & Dissatisfied & 13 & $8 \%$ \\
$15-19$ & Slightly & 30 & $18,5 \%$ \\
& dissatisfied & & \\
20 & Neutral & 5 & $3 \%$ \\
$21-25$ & Slightly & 49 & $30,2 \%$ \\
& Satisfied & & \\
$26-30$ & Satisfied & 53 & $32,7 \%$ \\
$31-35$ & Extremely & 12 & $7,4 \%$ \\
& satisfied & & \\
\hline
\end{tabular}

\begin{tabular}{|c|c|c|c|}
\hline \multicolumn{4}{|c|}{$\begin{array}{c}\text { Positive Affection (Positive and Negative Affect } \\
\text { Schedule) }\end{array}$} \\
\hline$<45,5$ & Low & 74 & $46 \%$ \\
\hline$>45,5$ & High & 88 & $54 \%$ \\
\hline \multicolumn{4}{|c|}{$\begin{array}{c}\text { Negative Affection (Positive and Negative Affect } \\
\text { Schedule) }\end{array}$} \\
\hline$<27,8$ & Low & 89 & $55 \%$ \\
\hline$>27,8$ & High & 73 & $45 \%$ \\
\hline
\end{tabular}

Table 3.

Classification of Father Involvement score

\begin{tabular}{llll}
\hline $\begin{array}{l}\text { Average } \\
\text { range }\end{array}$ & Categorize & Frequency & Percent \\
\hline$N F S$ & & & \\
$<3,63$ & Low & 71 & $44 \%$ \\
$>3,63$ & High & 91 & $56 \%$ \\
\hline$F I S-R$ & & & \\
$<3,40$ & Low & 83 & $51 \%$ \\
$>3,40$ & High & 79 & $49 \%$ \\
\hline
\end{tabular}

It can be seen from Table 3 that most parenting care involvement measured through NFS is in the high category $(56 \%)$. In the domain of father involvement reported, more participants were in the range below the mean of $51 \%$. On the FIS-R subscale measurements, it was found that the highest adolescent father involvement was on the Instrumental Involvement subscale with an average of 3.55 and a standard deviation of 0.68 . This means that most of the participants' fathers had more emphasis on involvement in the aspects of self-reliance, financial, moral development and career development in their care.

This is the main result relationship between perceive father involvement and early adolescent's subjective well-being.

The result of NFS measurement with SWB dimensions showed that there is a significant positive relationship to NFS score with positive affection score of PANAS with result of $r=0,265$ $p<0,05$. The result of the measurement of the negative affection also showed that there is a significant negative relationship between the NFS score with the negative Affected with the result of $\mathrm{r}=-0,219 \mathrm{p}<0,05$. Thus, the null hypothesis is rejected and the alternative hypothesis is accepted. This result means that the higher the father's care to the child relates with the higher positive affection on the child and the lower the child's negative affection. The higher the father's care in the domain of nurturance for children child will be happier. Furthermore, the following table 2 results of FIS-R score measurement with SWB dimensions.

Table 4.

Results of NFS Score Measurement with Dimensions of SWB

\begin{tabular}{|c|c|c|c|c|}
\hline Dimension & $\mathbf{R}$ & $\mathbf{r}^{2}$ & $\begin{array}{l}\text { Sig. (2- } \\
\text { tailed) }\end{array}$ & Note \\
\hline $\begin{array}{l}\text { Life } \\
\text { Satisfaction } \\
\text { (Satisfaction } \\
\text { With Life } \\
\text { Scale) }\end{array}$ & 0,129 & & 0,102 & $\begin{array}{l}\text { No } \\
\text { Significant }\end{array}$ \\
\hline $\begin{array}{l}\text { Positive } \\
\text { Affect } \\
\text { (Positive and } \\
\text { Negative } \\
\text { Affect Sch.) }\end{array}$ & 0,265 & 0,070 & 0,001 & Significant \\
\hline $\begin{array}{l}\text { Negative } \\
\text { Affect } \\
\text { (Positive and } \\
\text { Negative } \\
\text { Affect Sch.) }\end{array}$ & $\begin{array}{l}- \\
0,219\end{array}$ & 0,047 & 0,005 & Significant \\
\hline
\end{tabular}

Table 5.

Measurement Results Score FIS-R with Dimensions Subjective Well-being

\begin{tabular}{lcccc}
\hline \multicolumn{1}{c}{ Dimension } & $\mathbf{R}$ & $\mathbf{r}^{2}$ & $\begin{array}{c}\text { Sig. } \\
\mathbf{( 2 -} \\
\text { tailed) }\end{array}$ & Note \\
\hline $\begin{array}{l}\text { Life } \\
\text { Satisfaction } \\
\text { (Satisfaction }\end{array}$ & 0,076 & & 0,336 & $\begin{array}{c}\text { No } \\
\text { With Life }\end{array}$ \\
$\begin{array}{l}\text { Scale) } \\
\text { Positive }\end{array}$ & 0,291 & 0,084 & 0,000 & Significant \\
$\begin{array}{l}\text { Affect } \\
\text { (PANAS) }\end{array}$ & & & & \\
\hline \multicolumn{1}{c}{ Dimension } & $\mathbf{R}$ & $\mathbf{r}^{2}$ & $\begin{array}{c}\text { Sig. } \\
\mathbf{( 2 -} \\
\text { tailed) }\end{array}$ & Note \\
& & & 0,690 & No \\
\hline $\begin{array}{l}\text { Negative } \\
\text { Affect } \\
\text { (PANAS) }\end{array}$ & 0,032 & & & Significant \\
\hline
\end{tabular}


Table 5 showed that there is a significant positive relationship between NFS score with positive affection score of PANAS measurement with the result $r=0,291 \mathrm{p}<0,05$. Due to $\mathrm{p}<0.05$ then the null hypothesis is rejected and the alternative hypothesis is accepted. This means that the higher the father's involvement reported by the child relate to the higher of pleasure feeling what child feels.

From both correlation results, it can be seen that there is consistently both father domain involvement scores (NFS and FISR) which have a significant positive relationship with positive affection score of PANAS. But on the measurement results with the negative Affections of PANAS, only the NFS score has a relationship with the negative affection score of PANAS. In the cognitive dimension, consistent correlation results show that there is no significant relationship between both father involvement scores with the cognitive dimension score of SWB

\section{Discussion \& Conclusion}

Discussion. The purpose of this study was to examine the relationship between father involvement and subjective well-being. The results showed that there is a significant positive relationship between the father nurturance domain with the positive affection dimension of Subjective Well-being. This is in line with the results of research Ozdemir (2012). From these results, it can be interpreted that the father involvement in the domain of nurturance perceived positively by child. Diener and Scollon (2003) explained that when relationships in 3 areas (family, close friends, and romantic relationship partners) are perceived positively and pleasantly by someone, it can affect positive affection. It is also explained by Rodrigo, Byrne \& and Rodríguez (2014) that when children are given a good social environment, then it can increase the SWB of children. A good social environment is when the child feels comfortable in it and feels comfortable interacting with the people around him (Rodrigo, Byrne \& Rodríguez, 2014).

The results also show that there is a significant positive correlation between the reported father involvement domain with the positive affection dimension of Subjective Well-being. These results are in line with Ozdemir's study (2012). The father's involvement that has been accepted by the child is also perceived as pleasing to the child (Diener \& Scollon, 2003). This result is also supported by the results of the descriptive data that refers to subscale domain reported father involvement. The results showed that the average score on the instrumental involvement was 3.55 highest than another FIS-R subscales. Instrumental involvement involves aspects of career, discipline, independence development, developing a sense of responsibility and moral and ethical development. Reported involvement is positively perceived by teenagers. This is because, at this time, an adolescent is in need of care and direction to develop morale, independence and career in the future (Papalia \& Martorell, 2014). So when fathers get involved in that aspect, teenagers become more pleasant.

The three dimensions in SWB are related to each other (Diener \& Scollon, 2003). The result showed that most participants of 32.7 percent have satisfaction of life that is in the range of satisfied categories. How a person will evaluate his feelings depends heavily on the events in his life or his general condition of life (Diener \& Scollon, 2003). When a person is satisfied with their life, then they perceive the event that he feels is a fun thing for him (Diener \& Scollon, 2003).

The results of data processing on the dimensions of negative affection also indicate that there is a significantly negative relationship between father nurturance domain with the dimensions of negative affection of adolescents. Can be interpreted that the higher the parenting provided by the father relate with, the lower negative affection felt by the child. This is also in line with Ozdemir's (2012) research results. A significantly negative relationship between father nurturance domain and the negative affection indicates that father involvement that includes the warmth and acceptance of the father is perceived as pleasurable and can decrease the negative affection felt by the child. When spending time with the child and showing his warmth like playing together, sharing news, and providing emotional support (Carlson, 2006 in Lamb, 2010), the child becomes comfortable and it can improve the quality of father and child relationships (Amato, 1998, Furstenberg \& Harris, 1993; Lamb, 1997 in Allen \& Daly, 2002). The condition of the two affections is closely related because when a person feels positive affection, he does not feel a negative affection simultaneously (Diener \& Scollon, 2003). It can be interpreted that the 
pleasant feeling condition of the participant is accompanied by the negative affection condition which is also low.

The result of the relationship between father involvement and SWB cognitive dimension showed that there is no significant correlation between both father involvement domain and the cognitive dimension of Subjective Well-being. This is not in line with Ozdemir's (2012) study which showed that the warmth of the father is positively associated with the child's life satisfaction, as well as on Field et al's research (1995; Furstenberg \& Harris, 1993; Zimmerman et al., 1995; Harris et al., 1998; In Allen \& Daly, 2002) which showed the involvement of the father relate with positively with life satisfaction.

There are other factors that can relate to life satisfaction and father involvement. One of the factors that can affect the involvement of the father is how parenting style in educating their children. Marsigilio et al. (2000) in Lamb (2010) explains that paternal involvement is part of the parenting type of authoritative style. In authoritative parenting style, it is found that fathers spend time with children by providing emotional support, providing daily assistance, monitoring child behavior and using discipline methods that do not use physical violence (Carlson, as cited in Lamb, 2010). This type of parenting style is important because it will determine what kind of approach is done to the child (Rodrigo, Byrne \& Rodríguez, 2014), so in this case, parenting style can have an indirect relationship to the child's psychological wellbeing (Rodrigo, Byrne \& Rodríguez, 2014). In this study, the FIS-R score shows only the frequency of father involvement in the child's life aspect. However, from these scores, the researcher does not know what kind of approach is done by the father to engage in aspects of the child's life.

Another thing that can explain the satisfaction of life is the relationship of adolescents with peers (Ellison, 1990). In this phase, the adolescent tries to find their identity is through peers (Miller, 2011). Peers become significant figures because in adolescence they will explore themselves by hanging out with peers (Miller, 2011).

Therefore relationships with peers are important. The results of research from Ellison (1990) showed that the frequency of meeting with friends and availability of close friends has a significant relationship with life satisfaction. Bradburn et al.'s research (in Ellison, 1990) also found a significant relationship between adolescent friendship and life satisfaction. The reason is that in a relationship, teenagers can share the activities and values they understand, the affection, the hope, the pleasure and the benefits they desire.

The results of the descriptive cognitive dimension (life satisfaction) of participants showed that most of the $32.7 \%$ of participants fall into the satisfied category, with a score range of 26-30. It can be concluded that the participants in this study had high Subjective Well-being, because the participants were satisfied with their life, had a high positive affection and low negative affection. Suggestions for further research are to consider other factors such as parenting style types and relationships with friends related to father and SWB engagement. For practical advice, fathers are more involved in teenage life, especially in the father-nurturance domain, because the warmth of father and child relationships can improve the quality of relationships between the two. Increase the involvement of fathers in adolescent life, because it can increase positive affection and reduce negative affection in adolescents. When adolescents have a high positive affection, then the outcome of their daily behavior can also be more positive.

Conclusions. The conclusions of this research are there is a relationship between perceived father involvement and early adolescent's subjective well being. There is no significant relationship between Father Involvement and Satisfaction With Life Scale. There is a significant positive relationship between Nurturant Fathering Scale and positive affection. There is a significant negative relationship between Nurturant Fathering Scale and negative affection score measuring Positive and Negative Affect Schedule. There is a significant positive correlation between Father Involvement Scale-reported measurement scores with positive affection score of Positive and Negative Affect Schedule measuring instruments. There is no significant relationship between the scores of measurement Father Involvement Scale reported with negative affection score measuring instruments Positive and Negative Affect Schedule 


\section{References}

Allen, S., \& Daly, K. (2002). The effect of father involvement: An updated research summary of the evidence inventory. Canada: FIRA-CURA center for families, work, and well-being, University of Guelph.

Carlson, M. J. (2006). Family structure, father involvement, and adolescent behavioral outcomes. Journal of Marriage and Family, 68(1), 137-154.

Cripps, K., \& Zyromski, B. (2009). Adolescents' psychological well-being and perceived parental involvement: Implications for parental involvement in middle schools. RMLE Online, 33(4), 1-13.

Diener, E., Emmons, R. A., Larsen, R. J., \& Griffin, S. (1985). The Satisfaction with Life Scale. Journal of Personality Assessment, 49, 71-75.

Diener, E., Oishi, S., \& Lucas, R. E. (2003). Personality, culture, and subjective well-being: Emotional and cognitive evaluations of life. Annual review of psychology, 54(1), 403-425.

Diener, E., \& Scollon, C. (2003). Subjective well-being is desirable, but not the summum bonum. In University of Minnesota Interdisciplinary Workshop on WellBeing (pp. 23-25).

Ellison, C. G. (1990). Family ties, friendships, and subjective well-being among Black Americans. Journal of Marriage and the Family, 298-310.

Eryilmaz, A. (2011). Investigating adolescents' subjective well-being with respect to using subjective well-being increasing strategies and determining life goals. Dusunen Adam, 24(1), 44

Flouri, E., \& Buchanan, A. (2003). The role of father involvement and mother involvement in adolescents' psychological well-being. British Journal of Social Work, 33, 399-406.

Finley, G. E., \& Schwartz, S. J. (2004). The father involvement and nurturant fathering scales: Retrospective measures for adolescent and adult children. Educational and Psychological Measurement, 64(1), 143-164.

Ghaessani, F. (2011). Aku depresi, kalo kamu? Diunduh pada 19 Juni 2017 dari http://fetty14.blogspot.co.id/2011/07/aku-depresi-kalokamu.html.

Ghibran, R. M. (2010). Self- Efficacy dan Subjective Wellbeing pada Warga Bantaran Kali dan Warga yang Tinggal di Rumah Susun. Skripsi untuk memperoleh gelar sarjana. Universitas Indonesia, Depok, Indonesia.

Kumar, R. (2011). Research Methodology: A Step by step guide for beginners ( $3^{\text {rd }}$ ed). Los Angeles: SAGE Publication.

Lamb, M. (1986). The Father's Role Applied Perspectives. New York: John Wiley \& Sons, Inc.
Lamb, M. (2010). The Role of The Father in Child Development $\left(5^{\text {th }}\right.$ eds). John Wiley \& Sons, United States: John Wiley \& Sons Inc.

Lamb, M. E., Pleck, J. H., Charnov, E. L., \& Levine, J. A (1985). Paternal behavior in humans. American zoologist, 883-894.

Miller, P. (2011). Theories of Developmental Psychology (5th Ed). US: Worth Publishers

Monks, F. J., Knoers, A. M. P., \& Van de Vegt. (2002). Psikologi Perkembangan: Pengantar Dalam Berbagai Bagiannya. Jogjakarta: Gadjah Mada University Press.

Nastasi, B. K., \& Borja, A. P. (2016). International handbook of psychological well-being in children and adolescents. New York: Springer.

Nugrahani, H. Z. (2014). Hubungan Antara Prestasi Akademik dan Keterlibatan Ayah pada Remaja Sekolah Menengah Pertama. Skripsi untuk memperoleh gelar sarjana. Universitas Indonesia, Depok, Indonesia.

Oriza, I. I. D. (2016). Pengaruh Pemberian, Permintaan Terima Kasih dan Utang Budi terhadap Kesediaan Mengabulkan. Disertasi untuk memperoleh gelar doktoral. Universitas Indonesia, Depok, Indonesia.

Ozdemir, Y. (2012). Examining the Subjective Well-Being of Adolescents in terms of Demographic Variables, Parental Control, and Parental Warmth. Education \& Science/Egitim ve Özdemir, 37(165)

Papalia, D. E., \& Martorell, G. (2014). Experience Human Development $\left(13^{\text {th }}\right.$ ed). United States: Mc-Graw Hill Education.

Phares, V., Fields, S., \& Kamboukos, D. (2009). Fathers' and mothers' involvement with their adolescents. Journal of child and family studies, 18(1), 1-9.

Ramadhan, P. B. (2017). Gagal Bunuh Diri Karena ditolong Warga, Remaja 13 Tahun Ceburkan Diri Lagi ke Kali. Diunduh pada 19 Juni 2017 dari http://wartakota.tribunnews.com/2017/01/29/gagalbunuh-diri-karena-ditolong-warga-remaja-13-tahunceburkan-diri-lagi-ke-kali.

Rodrigo, M. J., Byrne, S., \& Rodríguez, B. (2014). Parenting styles and child well-being. In Handbook of child wellbeing (pp. 2173-2196). Springer Netherlands.

Rizqi, S. (2011). Tertekan, depresi, atau... Diunduh pada 19 Juni 2017 dari http://sarahrizqi.blogspot.co.id/2011/04/tertekandepresi-atau.html.

Watson, D., Clark, L. A., \& Tellegan, A. (1988). Development and validation of brief measures of positive and negative affect: The PANAS scales. Journal of Personality and Social Psychology, 54(6), 1063-1070. 